Article

\title{
Phytotoxicity of Essential Oils on Selected Weeds: Potential Hazard on Food Crops
}

\author{
María Dolores Ibáñez (i) and María Amparo Blázquez *(i) \\ Departament de Farmacologia, Facultat de Farmàcia, Universitat de València, Avd. Vicent Andrés Estellés s/n, \\ 46100 Burjassot, Valencia, Spain; mijai@alumni.uv.es \\ * Correspondence: amparo.blazquez@uv.es; Tel.: +34-963-544-945
}

Received: 11 September 2018; Accepted: 20 September 2018; Published: 22 September 2018

check for updates

\begin{abstract}
The chemical composition of winter savory, peppermint, and anise essential oils, and in vitro and in vivo phytotoxic activity against weeds (Portulaca oleracea, Lolium multiflorum, and Echinochloa crus-galli) and food crops (maize, rice, and tomato), have been studied. Sixty-four compounds accounting for between $97.67-99.66 \%$ of the total essential oils were identified by Gas Chromatography-Mass Spectrometry analysis. Winter savory with carvacrol (43.34\%) and thymol $(23.20 \%)$ as the main compounds produced a total inhibitory effect against the seed germination of tested weed. Menthol (48.23\%), menthone (23.33\%), and iso-menthone (16.33\%) from peppermint only showed total seed germination inhibition on L. multiflorum, whereas no significant effects were observed with trans-anethole $(99.46 \%)$ from anise at all concentrations $(0.125-1 \mu \mathrm{L} / \mathrm{mL})$. Low doses of peppermint essential oil could be used as a sustainable alternative to synthetic agrochemicals to control L. multiflorum. The results corroborate that in vivo assays with a commercial emulsifiable concentrate need higher doses of the essential oils to reproduce previous in vitro trials. The higher in vivo phytotoxicity of winter savory essential oil constitutes an eco-friendly and less pernicious alternative to weed control. It is possible to achieve a greater in vivo phytotoxicity if less active essential oil like peppermint is included with other active excipients.
\end{abstract}

Keywords: winter savory; peppermint; essential oils; food crops; weed control; phytotoxicity

\section{Introduction}

The potential hazard to the environment and human health, as well as the emergence of resistant weeds, are still the main problems of the overuse of synthetic herbicides used to improve global crop productivity. The continuous use of glyphosate, marketed in 1974 as a highly effective broad-spectrum herbicide [1], has made particular populations, such as the annual ryegrass (Lolium rigidum L.) in Australia [2] or barnyardgrass (Echinochloa crus-galli (L.) Beauv.) in cotton fields of the midsouthern United States [3], become glyphosate-resistant [4]. Recently, glyphosate resistance has been described in many world-wide species, like common ragweed (Ambrosia artemisiifolia L.) in several row crops of the south-eastern USA, following other still unknown mechanisms of action [5]. Together, resistant problems; potential health risks including skin irritancy, muscle atrophy, and nerve axons damage with prolonged exposure; and the use of a surfactant to enhance penetration [6] can even induce acute poisoning in humans, as well as chronic and sub-chronic toxicity, which has been reported in mammals after the consumption of contaminated food [7]. As these problems have appeared, some other weed killers have been synthesised as alternative solutions. However, the latest generation of the synthetic triketone herbicide family (sulcotrione, mesotrione, and tembotrione) also has negative impacts in microbial edaphic communities or plants, and even their degradation products can be more toxic than those of the parent, leading to similar environmental problems to glyphosate [8]. 
Resistance to other agrochemicals has also been reported in Lolium spp., exhibiting resistance to ALS-inhibiting herbicides that hinder acetolactate synthase (ALS), the enzyme common to the biosynthesis of the branch-chain amino acids (valine, leucine, and isoleucine) and ACCase (acetyl-coenzyme A carboxylase) inhibitors [9]. Similarly, common purslane (Portulaca oleracea L.) has developed resistance against linuron, a selective pre- and early post-emergent herbicide, in carrot (Daucus carota) fields [10]. In summary, weeds have evolved resistance in most of the known herbicide sites of action, being reported in 75 crops of 69 countries [11]. So, it is necessary to find more eco-friendly and less hazardous natural alternatives than synthetic herbicides, without promoting the emergence of resistance. In terms of natural compounds, essential oils are well-known for their multiple biological properties: anti-inflammatory, anticancer, antiviral, repellent, antibacterial, antifungal, or antioxidant, and have been widely used in the perfumery, cosmetics, pharmaceutical, and food industry, also being investigated to control crop pests [12]. In this sense, Satureja montana L. (Lamiaceae) was the highest effective larvicide of the essential oils tested against Culex quinquefasciatus [13] and was particularly active against several of the most damaging phytopathogenic fungi (Fusarium, Alternaria, Rhizoctonia, Phytophthora, and Botrytis spp.) that are able to destruct plant tissues, mainly cereals [14].

According to their phytotoxic capacity, Satureja spp. have potential as natural herbicides due to their main components, carvacrol and thymol, which are able to decrease in vitro germination and the growth of lambsquarters, common purslane, and barnyardgrass [15].

Another interesting bioresource is peppermint (Mentha piperita L.) essential oil, because it is able to exert a higher antimicrobial effect against Escherichia coli, Staphylococcus aureus, and Candida albicans, as well as upper antioxidant activity in DPPH free radical scavenging and $\beta$-carotene/linoleic acid systems, compared to other plant species, such as Myrtus communis [16]. These characteristics make peppermint essential oil a possible suitable bio-preservative to prevent post-harvest food decay. In this sense, it could be used to delay mold formation and reduce the incidence of infections when included as part of a coating as a previous experiment with only low amounts of the volatile that were enough to control fungal rot affecting Vitis labrusca L. maintained fruit quality during storage [17]. Regarding our topic, it is one of the most phytotoxic essential oils of 12 aromatic species, including Thymus vulgaris and Salvia officinalis against Amaranthus retroflexus, Avena fatua, Bromus secalinus, and Centaurea cyanus [18]. In fact, a dose-dependent inhibition of seed germination percentage, root and shoot lengths, and dry weight of field bindweed (Convolvulus arvensis L.), purslane, and jungle rice (E. colonum L.) has been observed at different concentrations $(0,300,600,900,1200,1500$, and $1800 \mu \mathrm{L} / \mathrm{L})$ of peppermint essential oil, whereas horticultural crops such as tomato (Lycopersicon esculentum Mill.) and radish (Raphanus sativus L.) were even more susceptible [19].

On the other hand, it is also interesting to expand the research with anise (Pimpinella anisum L.) essential oil since it is an annual medicinal plant belonging to the Apiaceae family and popularly known for its widespread use in the food and drink industry [20]. Its essential oil has shown higher antioxidant activity in in vitro models than the synthetic antioxidants butylated hydroxyanisole (BHA) and butylated hydroxytoluene (BHT), being possibly used for protecting fat-containing foods [21]. Antibacterial effects [22], as well as antifungal capacity, against Saccharomyces cerevisiae, Aspergillus niger [23], Bipolaris/Dreschslera sorociniana, Fusarium subglutinans, Fusarium vertricilioides, Fusarium oxysporum, Fusarium tricinctum, Fusarium sporotrichioides, Fusarium equiseti, Fusarium incarnatum, Fusarium proliferatum, and Macrophomina phaseolina have been also demonstrated [24], especially against Saccharomyces cerevisiae, which was effectively inhibited by anethole, the main component of aniseed, with an MFC value of $200 \mu \mathrm{g} / \mathrm{mL}$ [25]. In addition, it has been able to exert an insecticidal effect against young larvae of the Colorado potato beetle [26]. According to its phytotoxic activity, it has been described as one of the least active Mediterranean essential oils: it has shown a lower in vitro inhibitory effect in the seed germination of garden cress (Lepidium sativum), even promoting its germination and/or radicle elongation, as well as in 
food crops, such as lettuce (Latuca sativa) [27]. Despite its low phytotoxic potential, it has exhibited an effective competitive ability on common purslane, common lambsquarters, black nightshade, and barnyardgrass, being more suitable in low-input agricultural systems [28]. However, due to the harmful capacity of herbicides to remain inactivated for months in the soil and food products later consumed, anise essential oil has been recently included as one of the volatiles able to decompose and/or inhibit the function of the herbicide, together with ginger, peppermint, juniper, and lemongrass essential oils, through the dissolution and alteration of its chemical structure. In this case, the primary degradation product after the application of these essential oils is aminomethylphosphonic acid (AMPA), which is detected in much lower amounts in soil than glyphosate [29].

So, the aims of this work are firstly to test the in vitro phytotoxic activity (of previously analysed commercial essential oils, winter savory, peppermint, and anise, in order to assure their main compounds by GC/MS) against seed germination and seedling growth of P. oleracea, a cosmopolitan annual weed of tropical and subtropical climates; L. multiflorum, because Lolium spp. has been ranked as one of the specimens most frequently exhibiting herbicide resistance in many countries [30-32]; and E. crus-galli, a serious weed of irrigation crops, especially rice. Secondly, we aim to corroborate in vivo the previous in vitro phytotoxic effect using a commercial emulsifiable concentrate with the more phytotoxic essential oils and finally, we will study their potential hazard against maize (Zea mays L.), rice (Oryza sativa L.), and tomato (Solanum lycopersicum L.) seeds in order to obtain selective bioherbicides for food crops.

\section{Results}

\subsection{Chemical Composition of Winter Savory, Peppermint, and Anise Essential Oils}

Sixty-four compounds accounting for $97.67-99.66 \%$ of the total commercial winter savory, peppermint, and anise essential oils were identified by GC/MS analysis. Components are clustered (Table 1) in homologous series of monoterpene hydrocarbons, oxygenated monoterpenes, sesquiterpene hydrocarbons, oxygenated sesquiterpenes, diterpene hydrocarbons, aromatic compounds, and others, and are listed according to Kovat's retention index calculated in GC on an apolar HP-5MS column.

In winter savory essential oil, the monoterpene compounds $(95.06 \%)$, both oxygenated $(71.90 \pm 0.08 \%)$, with 16 compounds identified and hydrocarbons $(23.16 \pm 0.33 \%)$ including 13 components, were the main qualitative and quantitative fractions found. The phenolic compounds carvacrol $(43.34 \pm 0.09 \%)$ and thymol $(23.20 \pm 0.06 \%)$, followed by their biogenetic precursors $p$-cymene $(11.41 \pm 0.01 \%)$ and $\gamma$-terpinene $(5.78 \pm 0.01 \%)$, were the main compounds of winter savory essential oil. Together, the oxygenated monoterpenes, linalool, became the next major constituent of this fraction, although at a far lower percentage $(2.34 \pm 0.01 \%)$. Other compounds were detected in lower quantities, such as terpinen-4-ol $(1.04 \pm 0.01 \%)$ and cis-sabinene hydrate $(0.20 \pm 0.01 \%)$. Among the sesquiterpene fraction $(3.46 \%)$, only relatively large amounts of the sesquiterpene hydrocarbon $\beta$-caryophyllene $(2.81 \pm 0.01 \%)$ were found, while the rest ranged from $0.03 \%$ for $\gamma$-cadinene to $0.31 \%$ for the oxygenated sesquiterpene caryophyllene oxide. Abietatriene $(0.06 \%)$ and eugenol $(0.05 \%)$ were the only diterpene hydrocarbon and phenylpropanoid detected in winter savory essential oil, respectively.

Regarding peppermint essential oil, oxygenated monoterpenes (94.77\%) with 12 compounds identified were the main qualitative and quantitative phytochemical group found. Sesquiterpene hydrocarbons at a far lower percentage $(2.49 \%)$ constituted the next phytochemical group. Oxygenated sesquiterpenes and others were found at percentages lower than $1 \%(0.26$ and $0.15 \%$, respectively). Finally, neither monoterpene hydrocarbons nor aromatic compounds were detected in the commercial peppermint essential oil analysed here. Between the 24 identified compounds in M. piperita, the oxygenated monoterpene menthol $(48.23 \pm 0.36 \%)$, followed by menthone $(23.33 \pm 0.59 \%)$ and its diasteromer iso-menthone $(16.33 \pm 0.03 \%)$, were the main compounds. Among the sesquiterpene hydrocarbons, only $\beta$-caryophyllene $(1.26 \pm 0.04 \%)$ 
reached a percentage higher than 1\%. E-nerolidol, spathulenol, and caryophyllene oxide were the only oxygenated sesquiterpenes identified, with each one reaching $0.09 \%$.

Table 1. Chemical composition of commercial S. montana, M. piperita, and P. anisum essential oils.

\begin{tabular}{|c|c|c|c|c|}
\hline RI & Compound & $\begin{array}{c}\text { S. montana } \\
\text { Peak Area }(\%)\end{array}$ & $\begin{array}{c}\text { M. piperita } \\
\text { Peak Area (\%) }\end{array}$ & $\begin{array}{c}\text { P. anisum } \\
\text { Peak Area (\%) }\end{array}$ \\
\hline \multicolumn{2}{|c|}{ Monoterpene hydrocarbons } & $23.16 \pm 0.33$ & - & - \\
\hline 931 & $\alpha$-Thujene & $0.88 \pm 0.01$ & - & - \\
\hline 939 & $\alpha$-Pinene & $0.77 \pm 0.00$ & - & - \\
\hline 953 & Camphene & $0.32 \pm 0.00$ & - & - \\
\hline 979 & $\beta$-Pinene & $0.11 \pm 0.08$ & - & - \\
\hline 993 & Myrcene & $1.39 \pm 0.01$ & - & - \\
\hline 1005 & $\alpha$-Phellandrene & $0.21 \pm 0.00$ & - & - \\
\hline 1012 & 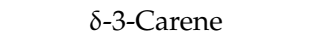 & $0.08 \pm 0.00$ & - & - \\
\hline 1019 & $\alpha$-Terpinene & $1.62 \pm 0.01$ & - & - \\
\hline 1029 & p-Cymene & $11.41 \pm 0.01$ & - & - \\
\hline 1033 & Limonene & $0.35 \pm 0.26$ & - & - \\
\hline 1053 & trans-Ocimene & $0.04 \pm 0.00$ & - & - \\
\hline 1063 & $\gamma$-Terpinene & $5.78 \pm 0.01$ & - & - \\
\hline 1090 & Terpinolene & $0.21 \pm 0.01$ & - & - \\
\hline \multicolumn{2}{|c|}{ Oxygenated monoterpenes } & $71.90 \pm 0.08$ & $94.77 \pm 0.07$ & - \\
\hline 1035 & 1,8-Cineole & $0.07 \pm 0.00$ & - & - \\
\hline 1070 & cis-Sabinene hydrate & $0.20 \pm 0.01$ & - & - \\
\hline 1098 & trans-Sabinene hydrate & $0.07 \pm 0.01$ & - & - \\
\hline 1101 & Linalool & $2.34 \pm 0.01$ & - & - \\
\hline 1146 & Camphor & $0.02 \pm 0.00$ & - & - \\
\hline 1150 & Isopulegol & - & $0.80 \pm 0.02$ & - \\
\hline 1155 & Menthone & - & $23.33 \pm 0.59$ & - \\
\hline 1164 & iso-Menthone & - & $16.33 \pm 0.03$ & - \\
\hline 1169 & Borneol & $0.71 \pm 0.02$ & & - \\
\hline 1176 & Menthol & - & $48.23 \pm 0.36$ & - \\
\hline 1179 & Terpinen-4-ol & $1.04 \pm 0.01$ & & - \\
\hline 1184 & iso-Menthol & - & $0.52 \pm 0.03$ & - \\
\hline 1186 & p-Cymen-8-ol & $0.02 \pm 0.01$ & & - \\
\hline 1188 & neo-iso-Menthol & - & $0.22 \pm 0.01$ & - \\
\hline 1191 & $\alpha$-Terpineol & $0.41 \pm 0.01$ & $0.26 \pm 0.01$ & - \\
\hline 1203 & trans-Dihydrocarvone & $0.03 \pm 0.01$ & $0.09 \pm 0.01$ & - \\
\hline 1237 & Methyl ether Thymol & $0.26 \pm 0.01$ & - & - \\
\hline 1242 & Pulegone & - & $0.85 \pm 0.06$ & - \\
\hline 1246 & Neral & $0.06 \pm 0.01$ & - & - \\
\hline 1249 & Carvone & $0.06 \pm 0.01$ & - & - \\
\hline 1256 & Piperitone & - & $0.68 \pm 0.06$ & - \\
\hline 1297 & Thymol & $23.20 \pm 0.06$ & - & - \\
\hline 1298 & Menthyl acetate & - & $3.38 \pm 0.26$ & - \\
\hline 1307 & iso-Menthyl acetate & - & $0.06 \pm 0.07$ & - \\
\hline 1314 & Carvacrol & $43.34 \pm 0.09$ & - & - \\
\hline 1374 & Carvacryl acetate & $0.08 \pm 0.01$ & - & - \\
\hline \multicolumn{2}{|c|}{ Sesquiterpene hydrocarbons } & $3.11 \pm 0.02$ & $2.49 \pm 0.04$ & $0.09 \pm 0.00$ \\
\hline 1338 & $\delta$-Elemene & - & $0.13 \pm 0.01$ & - \\
\hline 1351 & $\alpha$-Cubebene & - & $0.08 \pm 0.02$ & - \\
\hline 1388 & $\beta$-Bourbonene & - & $0.34 \pm 0.02$ & - \\
\hline 1390 & $\beta$-Elemene & - & $0.14 \pm 0.01$ & - \\
\hline 1416 & $\alpha$-cis-Bergamotene & - & - & $0.01 \pm 0.00$ \\
\hline 1420 & $\beta$-Caryophyllene & $2.81 \pm 0.01$ & $1.26 \pm 0.04$ & - \\
\hline 1437 & $\alpha$-trans-Bergamotene & - & - & $0.08 \pm 0.00$ \\
\hline 1454 & $\alpha$-Humulene & $0.11 \pm 0.01$ & - & - \\
\hline 1495 & Viridiflorene & $0.05 \pm 0.01$ & - & - \\
\hline 1500 & $\alpha$-Muurolene & - & $0.11 \pm 0.00$ & - \\
\hline 1509 & $\beta$-Bisabolene & $0.06 \pm 0.00$ & - & - \\
\hline 1514 & $\gamma$-Cadinene & $0.03 \pm 0.01$ & $0.12 \pm 0.00$ & - \\
\hline 1524 & $\delta$-Cadinene & $0.06 \pm 0.00$ & $0.30 \pm 0.01$ & - \\
\hline \multicolumn{2}{|c|}{ Oxygenated sesquiterpenes } & $0.35 \pm 0.02$ & $0.26 \pm 0.01$ & - \\
\hline
\end{tabular}


Table 1. Cont.

\begin{tabular}{|c|c|c|c|c|}
\hline RI & Compound & $\begin{array}{c}\text { S. montana } \\
\text { Peak Area (\%) }\end{array}$ & $\begin{array}{c}\text { M. piperita } \\
\text { Peak Area (\%) }\end{array}$ & $\begin{array}{c}\text { P. anisum } \\
\text { Peak Area (\%) }\end{array}$ \\
\hline 1565 & E-Nerolidol & - & $0.09 \pm 0.01$ & - \\
\hline 1578 & Spathulenol & $0.04 \pm 0.01$ & $0.09 \pm 0.00$ & - \\
\hline 1583 & Caryophyllene oxide & $0.31 \pm 0.01$ & $0.09 \pm 0.01$ & - \\
\hline \multicolumn{2}{|c|}{ Diterpene hydrocarbons } & $0.06 \pm 0.01$ & - & - \\
\hline 2067 & Abietatriene & $0.06 \pm 0.01$ & - & - \\
\hline \multicolumn{2}{|c|}{ Aromatic compounds } & $0.05 \pm 0.00$ & - & $99.57 \pm 0.05$ \\
\hline 1197 & Methyl Chavicol & - & - & $0.04 \pm 0.00$ \\
\hline 1253 & $p$-Anis aldehyde & - & - & $0.04 \pm 0.00$ \\
\hline 1255 & cis-Anethole & - & - & $0.03 \pm 0.00$ \\
\hline 1286 & trans-Anethole & - & - & $99.46 \pm 0.05$ \\
\hline 1359 & Eugenol & $0.05 \pm 0.00$ & - & - \\
\hline \multirow[t]{2}{*}{1406} & Methyl Eugenol & - & - & - \\
\hline & Others & $0.09 \pm 0.01$ & $0.15 \pm 0.02$ & - \\
\hline 980 & 1-Octen-3-ol & $0.09 \pm 0.01$ & - & - \\
\hline \multirow[t]{2}{*}{1275} & $n$-Decanol & - & $0.15 \pm 0.02$ & - \\
\hline & Total & $98.73 \pm 0.40$ & $97.67 \pm 0.08$ & $99.66 \pm 0.05$ \\
\hline
\end{tabular}

RI, retention index relative to C8-C32 n-alkane on HP-5MS column; values are mean \pm standard deviation of three samples.

Finally, in anise essential oil, the main phytochemical group was by far the aromatic fraction $(99.57 \pm 0.05 \%)$, with four compounds identified, in which the leading component was trans-anethole $(99.46 \pm 0.05 \%)$. The rest contained within this fraction did not reach percentages higher than $0.1 \%$ : methyl chavicol $(0.04 \%)$, $p$-anis aldehyde $(0.04 \%)$, and cis-anethole $(0.03 \%)$. Only two more compounds, the sesquiterpene hydrocarbons, $\alpha$-cis-bergamotene and $\alpha$-trans-bergamotene, were identified in P. anisum essential oil.

\subsection{Seed Germination and Seedling Growth Inhibition of P. oleracea, L. multiflorum, and E. crus-galli,} and Maize, Rice, and Tomato with Essential Oils

The phytotoxic effect of winter savory, peppermint, and anise essential oils was evaluated in vitro against three known harmful herbs: P. oleracea, L. multiflorum, and E. crus-galli. In this set of trials, the high phytotoxicity of winter savory essential oil (Table 2) was highly remarkable, exhibiting a total inhibitory effect against the seed germination of the tested weeds at all doses $(0.125,0.25,0.50$, and $1 \mu \mathrm{L} / \mathrm{mL}$ ) assayed.

Furthermore, it was also noteworthy that the complete inhibition of the seed germination of L. multiflorum by peppermint essential oil was exhibited at all doses $(0.125,0.25,0.50$, and $1 \mu \mathrm{L} / \mathrm{mL})$ applied (Table 2). Besides, significant differences between the control and the highest dose $(1 \mu \mathrm{L} / \mathrm{mL})$ of peppermint essential oil tested were found in the seed germination of both P. oleracea and E. crus-galli, although no significant effect at lower doses on the seed germination of P. oleracea and E. crus-galli was observed (Table 2).

In addition, a stronger phytotoxic effect was found with peppermint essential oil against the seedling growth (hypocotyl and radicle) of P. oleracea and E. crus-galli, so it could be employed as a potential post-harvest treatment. According to $P$. oleracea seedling growth, significant differences were found between the control and the higher doses $(0.50$ and $1 \mu \mathrm{L} / \mathrm{mL})$ tested (Table 3, Figure 1$)$. Lower doses of peppermint essential oil $(0.125$ and $0.25 \mu \mathrm{L} / \mathrm{mL})$ assayed did not cause a significant reduction in hypocotyl growth of P. oleracea seeds (37.25\%), whereas a moderate (50.98\%) inhibitory effect was observed when the highest dose $(1 \mu \mathrm{L} / \mathrm{mL})$ was applied. A similar result was found in radicle elongation, with a percentage inhibition of $43.48 \%$ at the two higher concentrations (Table 3). E. crus-galli seedling growth was more sensible to peppermint essential oil, experiencing a significant reduction in both hypocotyl and radicle development with respect to the control (Table 3, Figure 1b). There was no major difference in either hypocotyl or radicle enlargement when comparing 
concentrations $(0.125,0.25,0.50$, and $1 \mu \mathrm{L} / \mathrm{mL})$, achieving between $75.40-86.64 \%$ and $71.13-82.10 \%$ inhibition of hypocotyl and radicle expansion, respectively.

Table 2. In vitro effects of peppermint, anise, and winter savory essential oils against Portulaca oleracea, Lolium multiflorum, and Echinochloa crus-galli seed germination.

\begin{tabular}{cccc}
\hline \multicolumn{4}{c}{ Seed Germination (\% \pm e.d.) } \\
\hline \multirow{3}{*}{ Concentration $(\mu \mathrm{L} / \mathrm{mL})$} & \multicolumn{3}{c}{ Portulaca oleracea } \\
\cline { 2 - 4 } & Winter Savory & Peppermint & Anise \\
\hline Control & $85.00 \pm 2.74 \mathrm{a}$ & $85.00 \pm 2.74 \mathrm{a}$ & $85.00 \pm 2.74 \mathrm{a}$ \\
0.125 & $0.00 \pm 0.00 \mathrm{~b}$ & $81.00 \pm 2.45 \mathrm{a}, \mathrm{b}$ & $82.00 \pm 3.74 \mathrm{a}$ \\
0.25 & $0.00 \pm 0.00 \mathrm{~b}$ & $80.00 \pm 3.54 \mathrm{a}, \mathrm{b}$ & $85.00 \pm 5.24 \mathrm{a}$ \\
0.5 & $0.00 \pm 0.00 \mathrm{~b}$ & $75.00 \pm 3.87 \mathrm{a}, \mathrm{b}$ & $82.00 \pm 4.34 \mathrm{a}$ \\
1 & $0.00 \pm 0.00 \mathrm{~b}$ & $70.00 \pm 3.16 \mathrm{~b}$ & $81.00 \pm 1.87 \mathrm{a}$ \\
\hline \multirow{3}{*}{ Lolium multiflorum } \\
\hline \multirow{3}{*}{ Concentration $(\mu \mathrm{L} / \mathrm{mL})$} & Winter savory & Peppermint \\
\cline { 2 - 4 } Control & $67.00 \pm 5.15 \mathrm{a}$ & $67.00 \pm 5.15 \mathrm{a}$ & $67.00 \pm 5.15 \mathrm{a}$ \\
0.125 & $0.00 \pm 0.00 \mathrm{~b}$ & $0.00 \pm 0.00 \mathrm{~b}$ & $65.00 \pm 6.89 \mathrm{a}$ \\
0.25 & $0.00 \pm 0.00 \mathrm{~b}$ & $0.00 \pm 0.00 \mathrm{~b}$ & $64.00 \pm 4.30 \mathrm{a}$ \\
0.5 & $0.00 \pm 0.00 \mathrm{~b}$ & $0.00 \pm 0.00 \mathrm{~b}$ & $62.00 \pm 4.34 \mathrm{a}$ \\
1 & $0.00 \pm 0.00 \mathrm{~b}$ & $0.00 \pm 0.00 \mathrm{~b}$ & $60.00 \pm 3.54 \mathrm{a}$ \\
\hline \multirow{3}{*}{ Concentration $(\mu \mathrm{L} / \mathrm{mL})$} & \multicolumn{3}{c}{ Echinochloa crus-galli } \\
\cline { 2 - 4 } & Winter savory & Peppermint \\
\hline Control & $86.00 \pm 3.32 \mathrm{a}$ & $86.00 \pm 3.32 \mathrm{a}$ & $86.00 \pm 3.32 \mathrm{a}$ \\
0.125 & $0.00 \pm 0.00 \mathrm{~b}$ & $82.00 \pm 3.74 \mathrm{a}, \mathrm{b}$ & $89.00 \pm 1.87 \mathrm{a}$ \\
0.25 & $0.00 \pm 0.00 \mathrm{~b}$ & $82.00 \pm 2.55 \mathrm{a}, \mathrm{b}$ & $88.00 \pm 1.23 \mathrm{a}$ \\
0.5 & $0.00 \pm 0.00 \mathrm{~b}$ & $80.00 \pm 1.58 \mathrm{a}, \mathrm{b}$ & $83.00 \pm 2.55 \mathrm{a}$ \\
1 & $0.00 \pm 0.00 \mathrm{~b}$ & $72.00 \pm 2.00 \mathrm{~b}$ & $85.00 \pm 4.47 \mathrm{a}$ \\
\hline
\end{tabular}

Values are mean of five replications \pm error deviation after 14 days of incubation. Means followed by different letters in the same column indicate that they are significantly different at $p>0.05$ according to T3 Dunnet and Tukey tests.

Table 3. In vitro effects of peppermint essential oil against P. oleracea and E. crus-galli seedling growth.

\begin{tabular}{ccc}
\hline & \multicolumn{2}{c}{ Seedling Growth $(\mathrm{mm} \pm$ e.d.) } \\
\hline \multirow{3}{*}{ Concentration $(\mu \mathrm{L} / \mathrm{mL})$} & \multicolumn{2}{c}{ Peppermint } \\
\cline { 2 - 3 } & \multicolumn{2}{c}{ P. oleracea } \\
\cline { 2 - 3 } & Hypocotyl & Radicle \\
\hline Control & $10.20 \pm 0.58 \mathrm{a}$ & $13.80 \pm 2.04 \mathrm{a}$ \\
0.125 & $6.40 \pm 0.25 \mathrm{a}, \mathrm{b}$ & $11.80 \pm 1.39 \mathrm{a}, \mathrm{b}$ \\
0.25 & $6.40 \pm 0.25 \mathrm{a}, \mathrm{b}$ & $10.20 \pm 1.39 \mathrm{a}, \mathrm{b}$ \\
0.5 & $5.80 \pm 0.20 \mathrm{~b}$ & $7.80 \pm 0.37 \mathrm{~b}$ \\
1 & $5.00 \pm 0.00 \mathrm{c}$ & $7.80 \pm 0.97 \mathrm{~b}$ \\
\hline \multirow{3}{*}{ concentration $(\mu \mathrm{L} / \mathrm{mL})$} & \multicolumn{2}{c}{ E. crus-galli } \\
\cline { 2 - 3 } & Hypocotyl & Radicle \\
\hline Control & $23.66 \pm 3.80 \mathrm{a}$ & $20.78 \pm 1.78 \mathrm{a}$ \\
0.125 & $5.82 \pm 0.71 \mathrm{~b}$ & $6.00 \pm 1.03 \mathrm{~b}$ \\
0.25 & $4.56 \pm 0.37 \mathrm{~b}$ & $3.86 \pm 0.44 \mathrm{~b}$ \\
0.5 & $3.56 \pm 0.72 \mathrm{~b}$ & $4.34 \pm 0.52 \mathrm{~b}$ \\
1 & $3.16 \pm 0.69 \mathrm{~b}$ & $3.72 \pm 0.67 \mathrm{~b}$ \\
\hline
\end{tabular}

Values are mean of five replications \pm error deviation after 14 days of incubation. Means followed by different letters in the same column indicate that they are significantly different at $p>0.05$ according to T3 Dunnet and Tukey tests. 


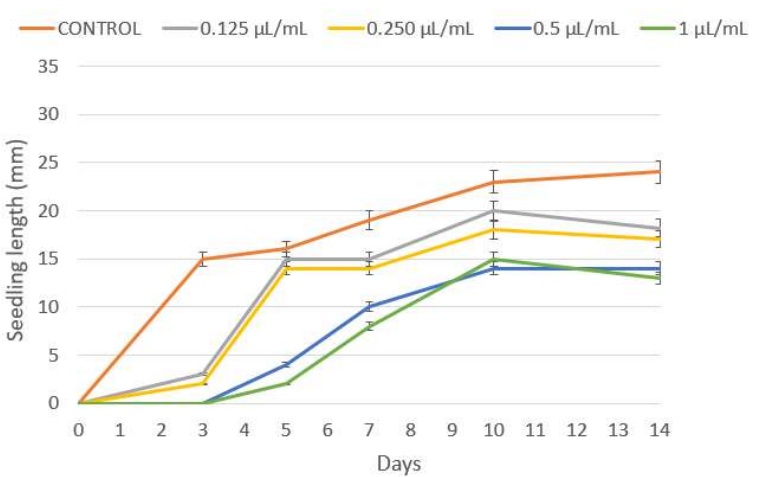

(a)

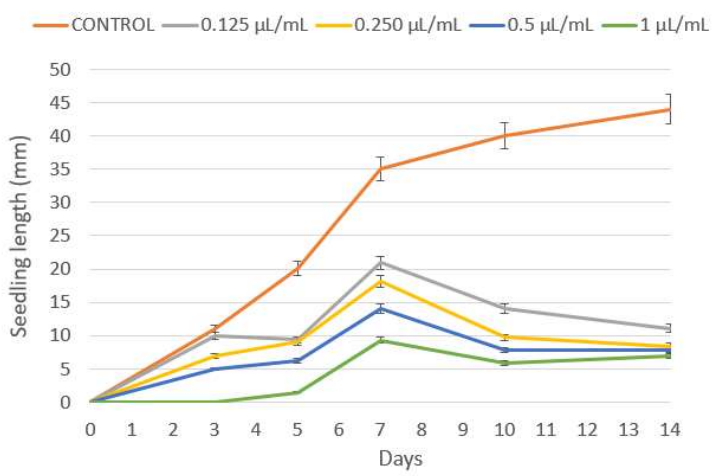

(b)

Figure 1. (a) P. oleracea and (b) E. crus-galli seedling growth with peppermint essential oil. Control and treated with peppermint essential oil at $0.125,0.25,0.50$, and $1 \mu \mathrm{L} / \mathrm{mL}$.

Anise essential oil showed the absence of a significant herbicidal effect for both the doses and weed species tried (Table 2). It displayed no significant phytotoxic activity against seed germination (Table 2) of weeds affecting food crops; however, the seedling growth (hypocotyl and radicle) of L. multiflorum was significantly inhibited in a dose-dependent manner (Table 4), as well as the hypocotyl development of E. crus-galli that was depleted $(63.23 \%)$ at the highest $(1 \mu \mathrm{L} / \mathrm{mL})$ dose and the radicle elongation at all concentrations applied with a percentage inhibition between 36.29 to $65.40 \%$ (Table 4, Figure 2c).

Table 4. In vitro effects of anise essential oil against P. oleracea and E. crus-galli seedling growth.

\begin{tabular}{ccc}
\hline & \multicolumn{2}{c}{ Seedling Growth (mm \pm e.d.) } \\
\hline \multirow{3}{*}{ Concentration $(\mu \mathrm{L} / \mathrm{mL})$} & \multicolumn{2}{c}{ Anise } \\
\cline { 2 - 3 } & \multicolumn{2}{c}{ P oleracea } \\
\cline { 2 - 3 } & Hypocotyl & Radicle \\
\hline Control & $10.20 \pm 0.58 \mathrm{a}$ & $13.80 \pm 2.04 \mathrm{a}$ \\
0.125 & $10.00 \pm 0.89 \mathrm{a}$ & $13.40 \pm 2.58 \mathrm{a}$ \\
0.25 & $9.60 \pm 0.68 \mathrm{a}$ & $13.60 \pm 2.36 \mathrm{a}$ \\
0.5 & $8.20 \pm 0.37 \mathrm{a}$ & $14.60 \pm 1.72 \mathrm{a}$ \\
1 & $7.60 \pm 1.60 \mathrm{a}$ & $13.40 \pm 1.60 \mathrm{a}$ \\
\hline \multirow{3}{*}{ Concentration $(\mu \mathrm{L} / \mathrm{mL})$} & \multicolumn{2}{c}{ L. multiflorum } \\
\cline { 2 - 3 } & Hypocotyl & Radicle \\
\hline Control & $48.50 \pm 3.35 \mathrm{a}$ & $39.14 \pm 2.14 \mathrm{a}$ \\
0.125 & $26.21 \pm 0.94 \mathrm{~b}$ & $27.65 \pm 1.25 \mathrm{~b}$ \\
0.25 & $23.07 \pm 1.17 \mathrm{~b}, \mathrm{c}$ & $21.29 \pm 2.05 \mathrm{~b}, \mathrm{c}$ \\
0.50 & $19.71 \pm 2.45 \mathrm{c}$ & $18.72 \pm 1.11 \mathrm{c}$ \\
1 & $12.66 \pm 0.61 \mathrm{~d}$ & $16.66 \pm 1.11 \mathrm{c}$ \\
\hline \multirow{2}{*}{ Concentration $(\mu \mathrm{L} / \mathrm{mL})$} & \multicolumn{2}{c}{ E. crus-galli } \\
\cline { 2 - 3 } & Hypocotyl & Radicle \\
\hline Control & $23.66 \pm 3.80 \mathrm{a}$ & $20.78 \pm 1.46 \mathrm{a}$ \\
0.125 & $19.82 \pm 0.95 \mathrm{a}$ & $13.24 \pm 0.30 \mathrm{~b}$ \\
0.25 & $18.64 \pm 1.17 \mathrm{a}$ & $12.90 \pm 0.27 \mathrm{~b}$ \\
0.5 & $14.44 \pm 0.30 \mathrm{a}, \mathrm{b}$ & $12.70 \pm 0.27 \mathrm{~b}$ \\
1 & $8.68 \pm 2.24 \mathrm{~b}$ & $7.19 \pm 1.35 \mathrm{~b}$ \\
\hline
\end{tabular}

Values are mean of five replications \pm error deviation after 14 days of incubation. Means followed by different letters in the same column indicate that they are significantly different at $p>0.05$ according to T3 Dunnet and Tukey tests. 


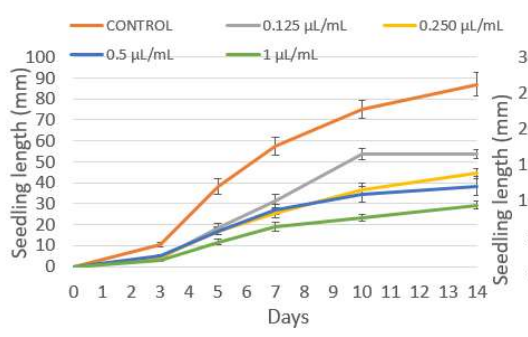

(a)

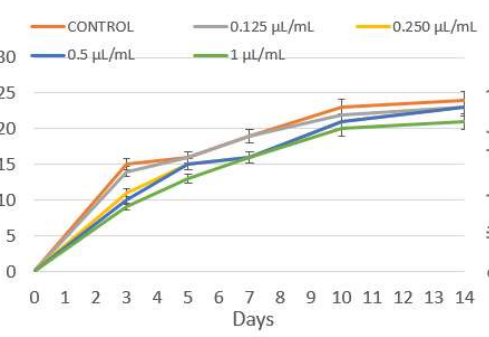

(b)

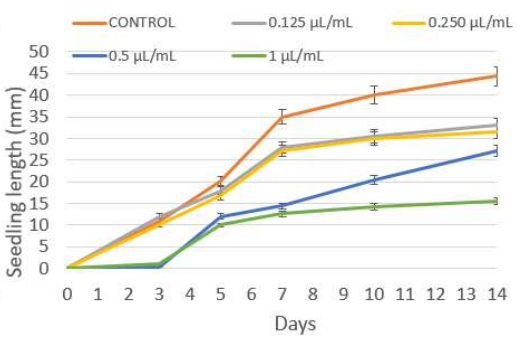

(c)

Figure 2. (a) L. multiflorum, (b) P. oleracea, and (c) E. crus-galli seedling growth. Control and treated with anise essential oil at $0.125,0.25,0.50$, and $1 \mu \mathrm{L} / \mathrm{mL}$.

The previous selective inhibitory effect at the concentrations applied displayed by peppermint essential oil against the three assayed weeds with a total L. multiflorum seed germination inhibition, was not observed against the three selected crops (Table 5). Tomato was the most sensible crop, with an almost complete seed germination inhibition (96.84\%) at the highest dose assayed $(1 \mu \mathrm{L} / \mathrm{mL})$, followed by maize $(79.31 \%$ ) and rice $(36.96 \%)$. Peppermint essential oil significantly affected the growth of both the hypocotyl and radicle of rice and tomato (Table 5). The maize radicle was also significantly disturbed by these treatments in comparison to the control, whereas the volatile oil did not affect the hypocotyl growth of maize. It is interesting to note the results of peppermint essential oil against rice and L. multiflorum, which show a lower phytotoxic effect in rice, with a seed germination inhibition percentage between $18.48 \%$ to $16.30 \%$ at the doses of $0.125,0.25$, and $0.50 \mu \mathrm{L} / \mathrm{mL}$ (Table 5); concentrations that cause a total seed germination inhibition of L. multiflorum, one of the principal weeds that affect this crop (Table 2).

Table 5. In vitro seed germination and hypocotyl and radicle growth of maize, rice, and tomato seeds with peppermint essential oil.

\begin{tabular}{|c|c|c|c|}
\hline \multirow{3}{*}{ Concentration $(\mu \mathrm{L} / \mathrm{mL})$} & Seed Germination $(\%) \pm$ e.d. & \multicolumn{2}{|c|}{ Seedling Growth ( $\mathrm{mm} \pm$ e.d.) } \\
\hline & \multicolumn{3}{|c|}{ Maize } \\
\hline & Germination & Hypocotyl & Radicle \\
\hline Control & $29.00 \pm 4.20 \mathrm{a}$ & $5.10 \pm 1.49 \mathrm{a}$ & $17.65 \pm 3.24 \mathrm{a}$ \\
\hline 0.125 & $15.00 \pm 3.25 b$ & $2.29 \pm 0.83 \mathrm{a}$ & $4.85 \pm 1.38 \mathrm{~b}$ \\
\hline 0.25 & $13.50 \pm 3.08 \mathrm{~b}$ & $2.31 \pm 0.36 \mathrm{a}$ & $3.95 \pm 0.89 \mathrm{~b}$ \\
\hline 0.5 & $7.50 \pm 2.27 b$ & $1.54 \pm 0.74 \mathrm{a}$ & $2.06 \pm 0.86 b$ \\
\hline 1 & $6.00 \pm 2.21 b$ & $1.72 \pm 0.64 \mathrm{a}$ & $2.15 \pm 0.74 b$ \\
\hline \multirow{2}{*}{ Concentration $(\mu \mathrm{L} / \mathrm{mL})$} & \multicolumn{3}{|c|}{ Rice } \\
\hline & Germination & Hypocotyl & Radicle \\
\hline Control & $92.00 \pm 2.55 \mathrm{a}$ & $22.29 \pm 5.72 \mathrm{a}$ & $33.52 \pm 5.90 \mathrm{a}$ \\
\hline 0.125 & $75.00 \pm 3.16 b$ & $5.64 \pm 1.43 \mathrm{~b}$ & $19.33 \pm 2.30 \mathrm{~b}$ \\
\hline 0.25 & $75.00 \pm 3.16 b$ & $5.47 \pm 1.74 \mathrm{~b}$ & $16.48 \pm 1.69 \mathrm{~b}$ \\
\hline 0.5 & $77.00 \pm 6.44 b$ & $6.85 \pm 1.68 b$ & $12.46 \pm 1.75 b$ \\
\hline 1 & $58.00 \pm 2.00 \mathrm{c}$ & $2.86 \pm 0.23 b$ & $7.25 \pm 0.47 b$ \\
\hline \multirow{2}{*}{ Concentration $(\mu \mathrm{L} / \mathrm{mL})$} & \multicolumn{3}{|c|}{ Tomato } \\
\hline & Germination & Hypocotyl & Radicle \\
\hline Control & $95.00 \pm 1.58 \mathrm{a}$ & $21.84 \pm 2.00 \mathrm{a}$ & $33.14 \pm 3.71 \mathrm{a}$ \\
\hline 0.125 & $39.00 \pm 12.59 \mathrm{~b}$ & $4.30 \pm 3.32 \mathrm{~b}$ & $9.61 \pm 5.23 b$ \\
\hline 0.25 & $31.00 \pm 16.08 \mathrm{~b}$ & $4.23 \pm 1.68 \mathrm{~b}$ & $7.70 \pm 2.67 b$ \\
\hline 0.5 & $14.00 \pm 4.30 \mathrm{c}$ & $1.48 \pm 0.63 \mathrm{~b}$ & $3.92 \pm 1.34 \mathrm{~b}$ \\
\hline 1 & $3.00 \pm 3.00 c$ & $0.20 \pm 0.20 \mathrm{~b}$ & $1.12 \pm 1.12 b$ \\
\hline
\end{tabular}

Values are mean of five replications \pm error deviation after 14 days of incubation. Means followed by different letters in the same column indicate that they are significantly different at $\mathrm{p}<0.05$ according to T3 Dunnet and Tukey tests. 
2.3. Seed Germination and Seedling Growth Inhibition of P. oleracea, L. multiflorum, and E. crus-galli, and Maize, Rice, and Tomato with an Emulsifiable Concentrate Including Winter Savory or Peppermint Essential Oils

The phytotoxic effect exhibited by winter savory and peppermint essential oils in in vitro trials were corroborated by in vivo conditions using two different emulsifiable concentrates elaborated by SEIPASA, a pioneer Spanish Company in the development, manufacturing, and marketing of environmentally friendly agro-inputs in order to produce healthy food.

The results of the emulsifiable concentrate containing a final dose of 5 or $10 \mu \mathrm{L} / \mathrm{mL}$ of essential oil were compared with a control watered with water and a blank without the corresponding essential oils.

The emulsifiable concentrate of winter savory succeeded in inhibiting the seed germination of P. oleracea within 33 days at both concentrations, corroborating the previous in vitro results in which there was also total inhibition of the weed germination of common purslane (Table 2).

Despite L. multiflorum and E. crus-galli being more tolerant species in in vivo conditions, the emulsifiable concentrate of winter savory also significantly inhibited their seed germination, with percentages of $95-100 \%$ and $82-99 \%$ at 5 and $10 \mu \mathrm{L} / \mathrm{mL}$, and without a significant effect with the blank (Figure 3). Similar results were found for hypocotyl growth (Figure 4), making the formulate with winter savory essential oil an ecological alternative to synthetic herbicides, which have already demonstrated a detrimental influence on the environment, crops, and human health.

Regarding peppermint essential oil, due to the less phytotoxical effect, it was emulsified with other herbicidal compounds (blank use by SEIPASA Company) and the formulate was able to inhibit the seed germination of the three weeds in a dose-dependent manner, with percentages between $77-100 \%$ for P. oleracea, $90-95 \%$ against E. crus-galli, and total inhibition over L. multiflorum, corroborating the in vitro results in which peppermint essential oil was more active against L. multiflorum than P. oleracea and E. crus-galli.

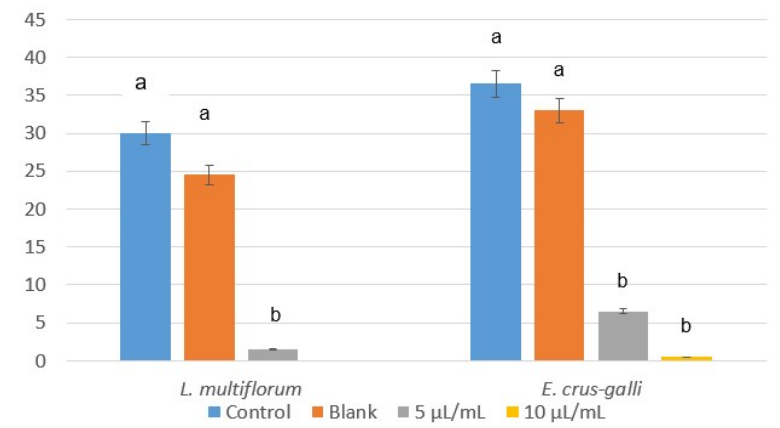

Figure 3. Values of seed germination (\%) of L. multiflorum and E. crus-galli control and blank, and treated with the emulsifiable concentrate of winter savory essential oil at 5 and $10 \mu \mathrm{L} / \mathrm{mL}$. Means followed by different letters in each column indicate that they are significantly different at $p<0.05$ according to T3 Dunnet and Tukey tests.

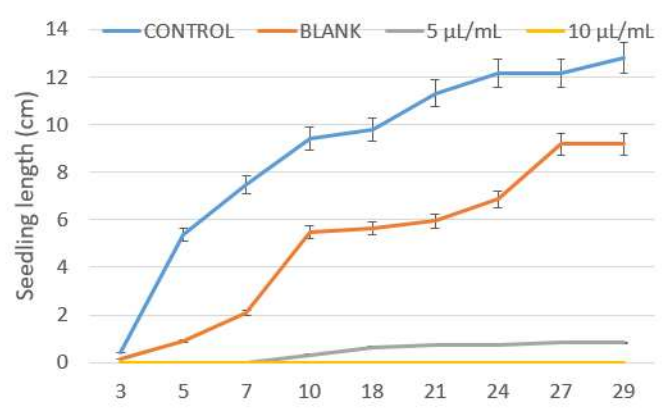

(a)

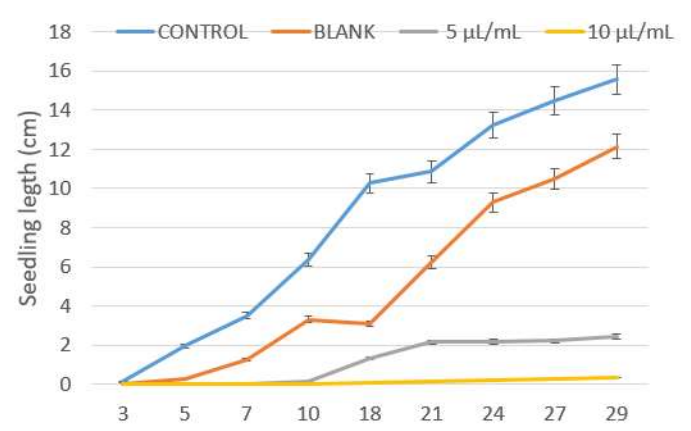

(b)

Figure 4. Hypocotyl growth (cm) of (a) L. multiflorum and (b) E. crus-galli control and blank, and treated with winter savory essential oil at 5 and $10 \mu \mathrm{L} / \mathrm{mL}$. 
According to the herbicidal effect of the emulsifiable concentrate of winter savory, a new set of trials was carried out with this formulate and three food crops. Unfortunately, a total seed germination inhibition was obtained with maize and rice, and between 80 and $98 \%$ of the tomato was inhibited at 5 and $10 \mu \mathrm{L} / \mathrm{mL}$, respectively, with no significant effect with the blank (Figure 5).

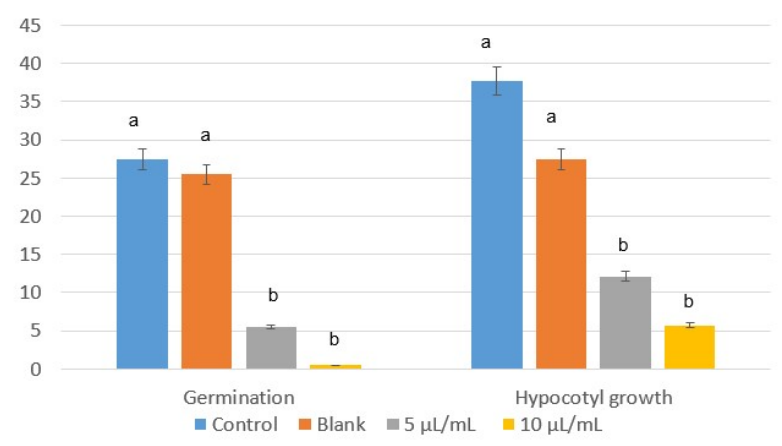

Figure 5. In vivo effect of the emulsifiable concentrate of winter savory essential oil over the germination and hypocotyl growth of tomato seeds. Values are mean of ten replications \pm error deviation after 30 days of incubation. Means followed by different letters in the same column indicate that they are significantly different at $p<0.05$ according to T3 Dunnet and Tukey tests.

\section{Discussion}

The phenolic compounds carvacrol $(43.34 \pm 0.09 \%)$ and thymol $(23.20 \pm 0.06 \%)$ were the main compounds identified in the winter savory essential oil analysed here. It is well-known that the strong spicy flavour of winter savory is determined by the prevailing carvacrol/thymol chemotype [33], which is variable in relation to the stage of development of the plant, harvesting time, and field environment conditions, including circumstances such as a variation in altitude: in fact, a higher content of linalool and other compounds found here in lower quantities (Table 1), such as terpinen-4-ol $(1.04 \pm 0.01 \%)$ and sabinene hydrate $(0.20 \pm 0.01 \%)$, has been detected in higher amounts in S. montana essential oil at a higher altitude, while both the major ones identified here, carvacrol and thymol, were quantified in lower percentages [34].

Apart from that, these phenolic compounds found in winter savory essential oil are considered the main bioactive monoterpenes that provide S. montana with a wide range of pharmacological and biological properties, such as natural antimicrobial activity [35] against gram-positive (Staphylococcus aureus and Bacillus cereus) and gram-negative bacteria (Salmonella infantis and Escherichia coli O157:H7) [36] that is useful in the treatment of foodborne diseases, as well as anti-inflammatory activity for certain transcription factors [37]. Furthermore, recently, some new thymol and carvacrol derivatives, including the carbamate moiety, have been synthesized with stronger inhibitory effects on acetylcholinesterase [38]. Related to their phytotoxicity, both carvacrol and thymol have shown total suppression of the seed germination and seedling growth of Amaranthus retroflexus, Chenopodium album, and Rumex crispus [39], coinciding with our authors [27] and also with previous [40] studies, in which oregano essential oil with $60.42 \%$ of carvacrol exhibited a total inhibition of P. oleracea, L. multiflorum, and E. crus-galli at the same in vitro doses assayed. These results indicate that winter savory is an effective broad-spectrum herbicide as it occurs with glyphosate that also exerts inhibitory effects on the seed germination of crops, such as wheat (Triticum durum L.), pea (Pisum sativum L.), lettuce (Latuca sativa L.) [41], and even trees, for instance Pinus pinaster, in which it is able to induce in vitro shoot chlorosis and drooping [42]. So, this formulate could be an alternative to glyphosate with less environmental and human health problems.

Several researches corroborate that the biological properties of peppermint essential oil are due to its chemical composition, especially its major components menthol, menthone, and iso-menthone [43,44], conferring the high percentage of menthol to peppermint essential oil immunostimulant effects in animals [45] and the herbicidal effect in Mediterranean weed, such as 
Amaranthus retroflexus L., Solanum nigrum L., and P. oleracea under controlled conditions [46]. The results obtained convert peppermint essential oil into a sustainable alternative that can solve the recent L. multiflorum resistance to glyphosate on rice paddy leaves [47]. Not only do our results match with other studies in reference to larger compounds, but also in reference to smaller ones, such as E-nerolidol, spathulenol, and caryophyllene oxide, which were the only oxygenated sesquiterpenes identified in peppermint essential oil $[48,49]$.

Finally, although trans-anethole, the main compound in commercial anise essential oil $(99.46 \pm 0.05 \%)$ analysed here and in other previous works [50] has demonstrated strong antifungal activity through the inhibition of the mycelial growth of a wide range of fungi [51] and could be used as a preservative in food preparation and processing [49], our results together with other research [52] revealed no significant phytotoxic activity against seed germination of selected weed.

\section{Materials and Methods}

\subsection{Essential Oil}

Commercial samples of winter savory (Satureja montana L.) (Batch 0054366), peppermint (Mentha piperita L.) (Batch 0058567), and anise (Pimpinella anisum L.) (Batch 0059857) essential oils supplied by Guinama (Valencia, Spain) were stored at $4{ }^{\circ} \mathrm{C}$ until chemical analysis and phytotoxic assays.

With the purpose of decreasing volatility, winter savory and peppermint essential oils were included in an emulsifiable concentrate industrially prepared by Seipasa Company that was stable at room temperature and adequate for in vivo weed control assays.

\subsection{Seeds}

Mature seeds of annual weeds of Portulaca oleracea L., Lolium multiflorum Lam., and Echinochloa crus-galli (L.) Beauv., were purchased from Herbiseed (website: www.herbiseed.com).

Mature seeds of 'Perseo-type' maize (Zea mays L.) and 'Albufera-type' rice (Oryza sativa L.) were obtained from the cereals in Sueca (Valencia, Spain). 'Huevo de toro-type' tomato (Solanum lycopersicum L.) seeds were directly acquired from the fruit found in the inner part in Utiel (Valencia, Spain).

\subsection{Gas Chromatography-Mass Spectrometry}

GC-MS analysis was carried out with a 5973N Agilent apparatus, equipped with a capillary column (95 dimethylpolysiloxane- 5\% diphenyl), Agilent HP-5MS UI (30 m long and $0.25 \mathrm{~mm}$ i.d. with $0.25 \mu \mathrm{m}$ film thickness). The column temperature program was $60^{\circ} \mathrm{C}$ for $5 \mathrm{~min}$, with $3{ }^{\circ} \mathrm{C} / \mathrm{min}$ increases to $180{ }^{\circ} \mathrm{C}$, and then $20^{\circ} \mathrm{C} / \mathrm{min}$ increases to $280{ }^{\circ} \mathrm{C}$, which was maintained for $10 \mathrm{~min}$. The carrier gas was Helium at a flow-rate of $1 \mathrm{~mL} / \mathrm{min}$. Split mode injection (ratio 1:30) was employed. Mass spectra were taken over the $m / z 30-500$ range with an ionizing voltage of $70 \mathrm{eV}$.

\subsection{Identification}

The individual compounds were identified by MS and their identity was confirmed by a comparison with their Kovat's retention index calculated using co-chromatographed standard hydrocarbons relative to C8-C32n-alkanes, and mass spectra with reference samples or with data already available in the NIST 2005 mass spectral library and in the literature [53].

4.5. In Vitro Assays: P. oleracea, L. multiflorum, E. crus-galli, Maize, Rice, and Tomato Seed Germination and Seedling Growth with Essential Oils

Sets of 20 seeds (10 for maize), each with five replicates (ten replicate in maize) per treatment, were homogenously distributed in Petri dishes $(9 \mathrm{~cm}$ diameter) between two layers of filter paper (Whatman No.1) moistened with $4 \mathrm{~mL}$ of distilled water and with 0 (control), 0.125, 0.250, 0.5, and $1 \mu \mathrm{L} / \mathrm{mL}$ of winter savory, peppermint, and anise essential oils. Petri dishes were sealed with 
parafilm and incubated in a germination chamber Equitec EGCS 301 3SHR model, according to previous assays [54], alternating between $30.0 \pm 0.1^{\circ} \mathrm{C} 16 \mathrm{~h}$ in light and $20.0 \pm 0.1{ }^{\circ} \mathrm{C} 8 \mathrm{~h}$ in dark, with (E. crus-galli, maize, and rice) and without (P.oleracea, L. multiflorum, and tomato) humidity. To evaluate the herbicidal activity of the essential oils, the number of germinated seeds was counted and compared with those of untreated seedlings. Emergence of the radicle $(\geq 1 \mathrm{~mm})$ was used as an index of germination and seedling length (hypocotyl and/or radicle) data were recorded after 3, 5, 7, 10 , and 14 days in each replicate.

\subsection{In Vivo Assays: P. oleracea, L. multiflorum, E. crus-galli, Maize, Rice, and Tomato with an Emulsifiable Concentrate of Winter Savory or Peppermint}

Ten seeds of each species (P. oleracea, L. multiflorum, E. crus-galli, maize, rice, and tomato) with ten replicates per treatment were randomly chosen and placed in pods $(9 \mathrm{~cm}$ diameter) with $40 \mathrm{~g}$ of substrate. They were place less than $1 \mathrm{~cm}$ below Substrate Projar Professional containing coir and peat make, fertilizer N-P-K: $14+16+18+$ micronutrients, and dolomitic limestone with a sorption capacity of $183 \mathrm{~g} / 10 \mathrm{~min}$. A set of 10 pods was watered on the first day with $20 \mathrm{~mL}$ of water (control), $20 \mathrm{~mL}$ commercial products (Nosbur OE 12 NS (32\% w/w), Emulson AG/CAL/E $(7 \% w / w)$, Emulson CO $36(13 \% w / w)$ or Emulson AG/CAL/E $(2.2 \% w / w)$, Alpicare $410 \mathrm{H}(21.7 \% w / w)$, Emulson AG/7720/A (2.6\% w/w) respectively) without essential oils (blank), and $20 \mathrm{~mL}$ of emulsifiable concentrate with winter savory $(48 \% w / w)$ or peppermint essential oil $(73.5 \% w / w)$ at 5 and $10 \mu \mathrm{L} / \mathrm{mL}$. A tray was used every five pods to hold and separate them when watering. In order to prevent leaching, the pods were covered with plastic film. Over a period of 33 or 20 days (winter savory or peppermint), each tray was watered with $250 \mathrm{~mL}$ of water every two days. The greenhouse conditions were: $23.3^{\circ} \mathrm{C}$ average indoor temperature, $18.1^{\circ} \mathrm{C}$ minimum indoor temperature, $29.7^{\circ} \mathrm{C}$ maximum indoor temperature, $57.2 \%$ average humidity, $80.9 \mu \mathrm{mol} / \mathrm{m}^{2} / \mathrm{s}$ PAR (Photo Active Radiation), and $135.6 \mathrm{~W} / \mathrm{m}^{2}$ intensity of radiation.

To evaluate the herbicidal effect, the number of germinated seeds in $5 \mu \mathrm{L} / \mathrm{mL}$ and $10 \mu \mathrm{L} / \mathrm{mL}$ pod trays was counted and compared with those of control and blank samples. Emergence of the hypocotyl $(\geq 1 \mathrm{~mm})$ was used as an index of germination and seedling length data were recorded every two days, coinciding with watering days over 33 or 20 days.

\subsection{Statistical Analysis}

Experiments were conducted with five replicates and ten replicates in vitro and in vivo, respectively. Data were subjected to one-way analysis of variance (ANOVA) with SPSS statistics 22 software. Tukey's post hoc test was used when variances remained homogeneous (Levene's test) and T3 Dunnett's post hoc one was employed if not, assuming equal variances. Differences were considered to be significant at $p \leq 0.05$.

\section{Conclusions}

The results in vitro showed that winter savory and peppermint essential oils can be effective bioherbicides. Peppermint essential oil at lower doses could be used to control L. multiflorum in rice. The emulsifiable concentrate based on winter savory essential oil tested in in vivo assays corroborates that this effective broad-spectrum herbicide constitutes an eco-friendly and less pernicious alternative to glyphosate in weed control.

Author Contributions: Conceptualization, M.A.B.; methodology, M.A.B.; formal analysis, M.D.I.; investigation, M.D.I.; resources, M.A.B.; data curation, M.D.I.; writing—original draft preparation, M.D.I.; writing-review and editing, M.D.I. and M.A.B.; visualization, M.D.I.; supervision, M.A.B.; project administration, M.A.B.

Funding: This research received no external funding.

Acknowledgments: The authors thank the Chief Research Officer at SEIPASA, Francisco Espinosa Escrig, for carrying out the stability tests and providing the emulsifiable concentrates of winter savory and peppermint 
essential oils for in vivo assays and the Central Service for Experimental Research of the University of Valencia (SCSIE) for providing the Greenhouse and Gas Chromatography- Mass Spectrometry equipment.

Conflicts of Interest: The authors declare no conflict of interest.

\section{References}

1. Duke, S.O.; Powles, S.B. Glyphosate: A once-in-a-century herbicide. Pest Manag. Sci. 2008, 64, 319-325. [CrossRef] [PubMed]

2. Powles, S.; Lorraine-Colwill, D.; Dellow, J.; Preston, C. Evolved resistance to glyphosate in rigid ryegrass (Lolium rigidum) in Australia. Weed Sci. 1998, 46, 604-607.

3. Bagavathiannan, M.V.; Norsworthy, J.K.; Smith, K.L.; Neve, P. Modeling the evolution of glyphosate resistance in barnyardgrass (Echinochloa crus-galli) in cotton-based production systems of the midsouthern United States. Weed Technol. 2013, 27, 475-487. [CrossRef]

4. Shaner, D.L.; Lindenmeyer, R.B.; Ostlie, M.H. What have the mechanisms of resistance to glyphosate taught us? Pest Manag. Sci. 2012, 68, 3-9. [CrossRef] [PubMed]

5. Nandula, V.K.; Tehranchian, P.; Bond, J.A.; Norsworthy, J.K.; Eubank, T.W. Glyphosate resistance in common ragweed (Ambrosia artemisiifolia L.) from Mississippi, USA. Weed Biol. Manag. 2017, 17, 45-53. [CrossRef]

6. Mariager, T.P.; Madsen, P.V.; Ebbehoj, N.E.; Schmidt, B.; Juhl, A. Severe adverse effects related to dermal exposure to a glyphosate-surfactant herbicide. Clin. Toxicol. 2013, 51, 111-113. [CrossRef] [PubMed]

7. Bai, S.H.; Ogbourne, S.M. Glyphosate: Environmental contamination, toxicity and potential risks to human health via food contamination. Environ. Sci. Pollut. Res. 2016, 23, 18988-19001. [CrossRef] [PubMed]

8. Dumas, E.; Giraudo, M.; Goujon, E.; Halma, M.; Knhili, E.; Stauffert, M.; Batisson, I.; Besse-Hoggan, P.; Bohatier, J.; Bouchard, P.; et al. Fate and ecotoxicological impact of new generation herbicides from the triketone family: An overview to assess the environmental risks. Hazard. Mater. 2017, 325, 136-156. [CrossRef] [PubMed]

9. Collavo, A.; Sattin, M. First glyphosate-resistant Lolium spp. biotypes found in a European annual arable cropping system also affected by ACCase and ALS resistance. Weed Res. 2014, 54, 325-334. [CrossRef]

10. Masabni, J.G.; Zandstra, B.H.; Yerkes, C.N.; Weller, S.C. Linuron resistance in Portulaca oleracea. In Proceedings of the Second International Weed Control Congress, Copenhagen, Denmark, 25-28 June 1996; pp. 571-575.

11. International Survey of Herbicide Resistant Weeds. Available online: http://www.weedscience.org/ Summary/MOA.aspx?MOAID=12 (accessed on 23 April 2017).

12. Isman, M.B. Plant essential oils for pest and disease management. Crop Prot. 2000, 19, 603-608. [CrossRef]

13. Benelli, G.; Pavela, R.; Canale, A.; Cianfaglione, K.; Ciaschetti, G.; Conti, F.; Nicoletti, M.; Senthil-Nathan, S.; Mehlhorn, H.; Maggi, F. Acute larvicidal toxicity of five essential oils (Pinus nigra, Hyssopus officinalis, Satureja montana, Aloysia citrodora and Pelargonium graveolens) against the filariasis vector Culex quinquefasciatus: Synergistic and antagonistic effects. Parasitol. Int. 2017, 66, 166-171. [CrossRef] [PubMed]

14. Fraternale, D.; Giamperi, L.; Bucchini, A.; Ricci, D.; Epifano, F.; Genovese, S.; Curini, M. Chemical composition and antifungal activity of the essential oil of Satureja montana from central Italy. Chem. Nat. Comp. 2007, 43, 622-624. [CrossRef]

15. Taban, A.; Saharkhiz, M.J.; Hadian, J. Allelopathic potential of essential oils from four Satureja spp. Biol. Agric. Hortic. 2013, 29, 244-257. [CrossRef]

16. Yadegarinia, D.; Gachkar, L.; Bagher Rezaei, M.; Taghizadeh, M.; Astaneh, S.A.; Rasooli, I. Biochemical activities of Iranian Mentha piperita L. and Myrtus communis L. essential oils. Phytochemistry 2006, 67, 1249-1255. [CrossRef] [PubMed]

17. Guerra, I.C.D.; de Oliveira, P.D.L.; Santos, M.M.F.; Lúcio, A.S.S.C.; Tavares, J.F.; Barbosa-Filho, J.M.; Madruga, M.S.; de Souza, E.L. The effects of composite coatings containing chitosan and Mentha (piperita L. or x villosa Huds) essential oil on postharvest mold occurrence and quality of table grape cv. Isabella. Innov. Food Sci. Emerg. Technol. 2016, 34, 112-121. [CrossRef]

18. Synowiec, A.; Kalemba, D.; Drozdek, E.; Bocianowski, J. Phytotoxic potential of essential oils from temperate climate plants against the germination of selected weeds and crops. J. Pest Sci. 2017, 90, 407-419. [CrossRef]

19. Mahdavikia, F.; Saharkhiz, J.M. Phytotoxic activity of essential oil and water extract of peppermint (Mentha $x$ piperita L. CV. Mitcham). J. Appl. Res. Med. Aromat. Plants 2015, 2, 146-153. [CrossRef] 
20. Tavalli, V.; Rahmati, S.; Bahmanzadegan, A. Antioxidant activity, polyphenolic contents and essential oil composition of Pimpinella anisum L. as affected by zinc fertilizer. J. Sci. Food Agric. 2017, 97, 4883-4889. [CrossRef] [PubMed]

21. Singh, G.; Kapoor, I.P.S.; Singh, P.; de Heluani, C.S.; Catalan, C.A.N. Chemical composition and antioxidant potential of essential oil and oleoresins from anise seeds (Pimpinella anisum L.). Int. J. Essent. Oil Ther. 2008, 2, 122-130.

22. Evrendilek, G.A. Empirical prediction and validation of antibacterial inhibitory effects of various plant essential oils on common pathogenic bacteria. Int. J. Food Microbiol. 2015, 202, 35-41. [CrossRef] [PubMed]

23. Fitsiou, E.; Mitropoulou, G.; Spyridopoulou, K.; Tiptiri-Koupeti, A.; Vamvakias, M.; Bardouki, H.; Panayiotidis, M.I.; Galanis, A.; Kourkoutas, Y.; Chlichlia, K.; et al. Phytochemical profile and evaluation of the biological activities of essential oils derived from the Greek aromatic plant species Ocimum basilicum, Mentha spicata, Pimpinella anisum and Fortunella margarita. Molecules 2016, 21, 1069. [CrossRef] [PubMed]

24. Starovic, M.; Ristic, D.; Pavlovic, S.; Ristic, M.; Stevanovic, M.; AlJuhaimi, F.; Svetlana, N.; Özcan, M.M.J. Antifungal activities of different essential oils against anise seeds mycopopulations. Food Saf. Food Qual. 2016, 67, 61-92.

25. Kubo, I.; Fujita, K.; Nihei, K. Antimicrobial activity of anethole and related compounds from aniseed. J. Sci. Food Agric. 2008, 88, 242-247. [CrossRef]

26. Skuhrovec, J.; Douda, O.; Pavela, R.; Klouček, P.; Bozik, M.; Zouhar, M. The effects of Pimpinella anisum essential oils on young larvae Leptinotarsa decemlineata Say (Coleoptera: Chrysomelidae). Am. J. Potato Res. 2017, 94, 64-69. [CrossRef]

27. De Almeida, L.F.R.; Frei, F.; Mancini, E.; De Martino, L.; De Feo, V. Phytotoxic activities of Mediterranean essential oils. Molecules 2010, 15, 4309-4323. [CrossRef] [PubMed]

28. Dhima, K.; Vasilakoglou, I.; Garane, V.; Ritzoulis, C.; Lianopoulou, V.; Panou-Philotheou, E. Competitiveness and essential oil phytotoxicity of seven annual aromatic plants. Weed Sci. 2010, 58, 457-465. [CrossRef]

29. Young, D.G. Composition and Method for Treating an Herbicide. U.S. Patent 20170056941 A1, 2 March 2017.

30. Fernández-Moreno, P.T.; Bastida, F.; De Prado, R. Evidence, mechanism and alternative chemical seedbank-level control of glyphosate resistance of a rigid ryegrass (Lolium rigidum) biotype from Southern Spain. Front. Plant Sci. 2017, 8, 450. [CrossRef] [PubMed]

31. Vargas, L.; Ruchel, Q.; Agostinetto, D.; Lamego, F.P.; Langaro, A.C.; Piesanti, S.R. Verification of the mechanism of glyphosate resistance in Italian ryegrass biotype. Planta Daninha 2016, 34, 565-573. [CrossRef]

32. Yanniccari, M.; Vila-Aiub, M.; Istilart, C.; Acciaresi, H.; Castro, A.M. Glyphosate resistance in perennial ryegrass (Lolium perenne L.) is associate with a fitness penalty. Weed Sci. 2016, 64, 71-79. [CrossRef]

33. Trifan, A.; Aprotosoaie, A.C.; Brebu, M.; Cioanca, O.; Gille, E.; Hancianu, M.; Miron, A. Chemical composition and antioxidant activity of essential oil from Romanian Satureja montana L. Farmacia 2015, 63, 413-416.

34. Mihajilov-Krestev, T.; Radnovic, D.; Kitic, D.; Jovanovic, V.S.; Mitic, V.; Stojanovic-Radic, Z.; Zlatkovic, B. Chemical composition, antimicrobial, antioxidative and anticholinesterase activity of Satureja montana L. ssp montana essential oil. Cent. Eur. J. Biol. 2014, 9, 668-677. [CrossRef]

35. Teixeira, B.; Marques, A.; Ramos, C.; Serrano, C.; Matos, O.; Neng, N.R.; Nogueira, J.M.F.; Saraiva, J.A.; Nunes, M.L. Chemical composition and bioactivity of different oregano (Origanum vulgare) extracts and essential oil. J. Sci. Food Agric. 2013, 93, 2707-2714. [CrossRef] [PubMed]

36. Gavaric, N.; Mozina, S.S.; Kladar, N.; Bozin, B. Chemical profile, antioxidant and antibacterial activity of thyme and oregano essential oils, thymol and carvacrol and their possible synergism. J. Essent. Oil Bear. Plants 2015, 18, 1013-1021. [CrossRef]

37. Gholijani, N.; Gharagozloo, M.; Farjadian, S.; Amirghofran, Z. Modulatory effects of thymol and carvacrol on inflammatory transcription factors in lipopolysaccharide-treated macrophages. J. Immunotoxicol. 2016, 13, 157-164. [CrossRef] [PubMed]

38. Kurt, B.Z.; Gazioglu, I.; Dag, A.; Salmas, R.E.; Kayik, G.; Durdagi, S.; Sonmez, F. Synthesis, anticholinesterase activity and molecular modelling study of novel carbamate-substituted thymol/carvacrol derivatives. Bioorg. Med. Chem. Lett. 2017, 25, 1352-1363. [CrossRef] [PubMed]

39. Kordali, S.; Cakir, A.; Ozer, H.; Cakmakci, R.; Kesdek, M.; Mete, E. Antifungal, phytotoxic and insecticidal properties of essential oil isolated from Turkish Origanum acutidens and its three components, carvacrol, thymol and p-cymene. Bioresour. Technol. 2008, 99, 8788-8795. [CrossRef] [PubMed] 
40. Ibáñez, M.D.; Blázquez, M.A. Herbicidal value of essential oils from oregano-like flavour species. Food Agric. Immunol. 2017, 28, 1168-1180. [CrossRef]

41. Grosso, C.; Coelho, J.A.; Urieta, J.S.; Palabra, A.M.F.; Barroso, J.G. Herbicidal activity of volatiles from coriander, winter savory, cotton lavender, and thyme isolated by hydrodistillation and supercritical fluid extraction. J. Agric. Food Chem. 2010, 58, 11007-11013. [CrossRef] [PubMed]

42. Faria, J.M.S.; Sena, I.; Moiteiro, C.; Bennett, R.; Mota, M.; Figueiredo, A.C. Nematoxic and phytotoxic activity of Satureja montana and Ruta graveolens essential oils on Pinus pinaster shoot cultures and P. pinaster with Bursaphelenchus xylophilus in vitro co-cultures. Ind. Crops Prod. 2015, 7, 59-65. [CrossRef]

43. Fatemi, F.; Dini, S.; Rezaei, M.B.; Dadkhah, A.; Dabbagh, R.; Naij, S. The effect of $\gamma$-irradiation on the chemical composition and antioxidant activities of peppermint essential oil and extract. J. Essent. Oil Res. 2014, 26, 97-104. [CrossRef]

44. Kamatou, G.P.P.; Vermaak, I.; Viljoen, A.M.; Lawrence, B.M. Menthol: A simple monoterpene with remarkable biological properties. Phytochemistry 2013, 96, 15-25. [CrossRef] [PubMed]

45. Awaad, M.H.H.; Abdel-Alim, G.A.; Sayed, K.S.S.; Ahmed, K.A.; Nada, A.A.; Metwalli, A.S.Z.; Alkhalaf, A.N. Immunostimulant effects of essential oils of peppermint and eucalyptus in chickens. Pak. Vet. J. 2010, 30, 61-66.

46. Cavalieri, A.; Caporali, F. Effects of essential oils of cinnamon, lavender and peppermint on germination of Mediterranean weeds. Allelopath. J. 2010, 25, 441-452.

47. Niinomi, Y.; Ikeda, M.; Yamashita, M.; Ishida, Y.; Asai, M.; Shimono, Y.; Tominaga, T.; Sawada, H. Glyphosate-resistant Italian ryegrass (Lolium multiflorum) on rice paddy levees in Japan. Weed Biol. Manag. 2013, 13, 31-38. [CrossRef]

48. Grulova, D.; De Martino, L.; Mancini, E.; Salamon, I.; De Feo, V. Seasonal variability of the main components in essential oil of Mentha x piperita L. J. Sci. Food Agric. 2014, 95, 621-627. [CrossRef] [PubMed]

49. Özcan, M.M.; Chalchat, J.C. Chemical composition and antifungal effect of anise (Pimpinella anisum L.) fruit oil at ripening stage. Ann. Microbiol. 2006, 5, 353-358. [CrossRef]

50. Hussain, A.I.; Anwar, F.; Nigam, P.S.; Ashraf, M.; Gilani, A.H. Seasonal variation in content, chemical composition and antimicrobial and cytotoxic activities of essential oils from four Mentha species. J. Sci. Food Agric. 2010, 90, 1827-1836. [CrossRef] [PubMed]

51. Shukla, H.S.; Tripathi, S.G. Antifungal substance in the essential oil of anise (Pimpinella anisum L.). Agric. Biol. Chem. 1987, 51, 1991-1993. [CrossRef]

52. Sharma, P.K.; Raina, A.P.; Dureja, P. Evaluation of the antifungal and phytotoxic effects of various essential oils against Sclerotium rolfsii (Sacc) and Rhizotonia bataticola (Taub). Arch. Phytopathol. Plant Prot. 2009, 42, 65-72. [CrossRef]

53. Adams, R.P. Identification of Essential Oil Components by Gas Chromatography/Mass Spectrometry; Allured Publishing Corporation: Carol Stream, IL, USA, 2007.

54. Blázquez, M.A.; Carbó, E. Control of Portulaca oleracea by boldo and lemon essential oils indifferent soils. Ind. Crops Prod. 2015, 76, 515-521. [CrossRef]

(c) 2018 by the authors. Licensee MDPI, Basel, Switzerland. This article is an open access article distributed under the terms and conditions of the Creative Commons Attribution (CC BY) license (http:// creativecommons.org/licenses/by/4.0/). 